\title{
Islamic Law Perspective on Settlement of Inheritance Disputes
}

\author{
Arsyam Arsyam $^{1 *}$, Siti Musyahidah², Malkan Malkan³
}

${ }^{1}$ Islamic Family Law Department, Postgraduate, Institut Agama Islam Negeri Palu

2 Islamic Family Law Department, Postgraduate, Institut Agama Islam Negeri Palu

${ }^{3}$ Islamic Family Law Department, Postgraduate, Institut Agama Islam Negeri Palu

\begin{abstract}
This study discusses the process of inheritance dispute resolution in the Religious Court of Palu City. This study is a literature review study. While the approach used in this study is a normative approach, which is based on the texts of the Qur'an, AlHadith and a juridical approach, which is based on the compilation of Islamic law and the Law of Religion Court authority. This research data analysis method uses an inductive pattern, which is an analysis that departs from concrete facts or events in the decisions of the Religious Courts even to the Supreme court then general conclusion was drawn. This research is descriptive-analytical in nature, namely research that seeks to describe the process of resolving inheritance disputes in the Palu city religious court. Then in the analysis, the researcher tried to find the Islamic law perspective on the settlement of inheritance disputes. The results showed that the process of inheritance dispute resolution is the same as other litigation processes through the stage of registration entered into the head of the court then the head of the court determines 3 judges in handling the case of inheritance dispute. The distribution of inheritance at the Palu Religious Court carried out through a consensus by going through several stages in the trial channel. In that stage, it included the Palu Religious Court, then appealed to the high court until the end of the case of inheritance reached the Supreme Court. This is done in order to maintain the mutual benefit of the family suing each other.
\end{abstract}

ARTICLE

INFORMATION

\author{
Keywords: \\ Islamic law, \\ settlement, inheritance \\ disputes
}




\section{Introduction}

Inheritance arises because of death. This death event occurs in one of the family members, for example, father, mother, or child. ${ }^{1}$ If the person who dies has property, then the main issue is not the event of the death, but the property left behind. Inheritance on the one hand is rooted in family, and on the other hand is rooted in wealth. Rooted in the family because it involves who is the heirs, and rooted in wealth because it involves inheritance rights to the assets left behind by a person who dies. ${ }^{2}$

In the Civil Code Book II Chapter 12 and 18, it is regulated that if the inheritance law of the Civil Code is related to the hereditary system, then it adheres to a bilateral hereditary system, where everyone connects himself with the descendants of his father and mother, meaning that the heir has the right to inherit from the father if the father dies and has the right inherit from mother if mother dies. ${ }^{3}$

When connected with the inheritance system, the Civil Code

1 For more study of family in relation to the prevention of social conflict, see Rusli Rusli, "The Role of Family in Preventing Social Conflict in Society From Islamic Perspectives," HUNAFA: Jurnal Studia Islamika 17, no. 1 (2020): 108-122.

22 Rusli Rusli, "An Analysis of Islamic Feminism in Indonesia: Reconstruction of Islamic Legal Issues on Gender Relations," Hunafa: Jurnal Studia Islamika 3, no. 1 (2006): 1-12, https://www.jurnalhunafa.org/index.php/huna fa/article/view/239.;See also Rusli Rusli, Islamic Feminism: Responses of Muslim Feminists to Gender Inequality in Indonesia (Palu: Irshed Press, 2006).

${ }^{3}$ Abdul Kadir Muhammad, Hukum Waris Menurut KUH Perdata (Bandung: Citra Aditya Bhakti, 2000), 267. adheres to an individual inheritance system, since the opening of inheritance. Most of the Indonesian population embraces Islam, referring to the Qur'an and Sunnah, so that Indonesia can internalize the teachings of Islam contained in the Quran and Hadith.

Religious Courts are the institutions serve to administer judicial power to enforce law and justice which have the following scope and authority: (1) Judiciary for Muslim people seeking justice; (2) Examine, decide and settle certain civil cases in the fields of: (a) marriage, (b) inheritance, wills and grants based on Islam; (c) waqf and alms. ${ }^{4}$

The procedural law of the Religious Courts is based on two rules, namely: (1) those contained in Law Number 7 of 1989 on Religious Courts, and: (2) those that apply within the General Courts. According to the provisions of Law Number 7 of 1989 Article 54, "Procedural law that applies to the courts within the Religious Courts is the Civil Procedure Law that applies to the courts within General Courts, except those specifically regulated in this Law" ${ }^{5}$

These provisions indicate that there is a Civil Procedure Code which generally applies to the courts within the General and Religious Courts, and there

${ }^{4}$ Cik Hasan Bisri, Peradilan Agama di Indonesia (Jakarta: PT Raja Grafindo Persada, 2000), 241.

5 Sukaenah, Sukaenah, Rusli, Rusli, \& B, M. Taufan. (2020). The Effectiveness of Indonesia Supreme Court Regulation Number 1 Year 2016 Concerning Mediation of Marriage Disputes International Journal Of Contemporary Islamic Law And Society, 2(1), 63-80.

e-ISSN: $2715-4580$ p-ISSN: $2715-8268$ 
is also a procedural law which only applies to courts within the Religious Courts. ${ }^{6}$

In the case of inheritance disputes, for example, sometimes there are differences of opinion in the distribution of inheritance between the parties. If the parties fail to find the right solution, then this difference of opinion can be bad for the continuity of the relationship between the parties. Therefore, when they face a difference of opinion, the parties always try to find the right solution according to the agreement of the parties to the dispute. There is a desire of the litigants in inheritance cases to resolve them in a familial way. However, the inheritance issue that was not resolved amicably between the parties to the case was finally brought to the Religious Court.

The death of a person results in the emergence of a branch of jurisprudence concerning the settlement of the distribution of inheritance, known as figh Mawaris or Faraid. ${ }^{7}$ Islamic law stipulates inheritance rules very systematically and full of justice values. ${ }^{8}$

However, in reality, there are often disputes over inheritance issues. One of the institutions that deal with inheritance disputes is the Religious Courts. In the

6 Undang-Undang No. 7 Tahun 1989 (Semarang : Aneka Ilmu, 1990), 23.

7Suparman Usman and Yusuf Somawinata, Figh Mawaris: Hukum kewarisan Islam (Jakarta: Tintamas,1982), 9.

8 See Rusli Rusli, "Gagasan Khaled Abu Fadl Tentang "Islam Moderat Versus Islam Puritan (Perspektif Sosiologi Pengetahuan)," Jurnal Ilmiah Ilmu Ushuluddin 8, no. 1 (2009): 99123. context of Palu, it is the Religious Court Class 1 Palu. This institution is a litigation body that deals with cases specifically for Muslims in Indonesia, in accordance with Law Number 3 of 2006, which is a revision of Law Number 7 of 1989.

The people of Palu, which are multicultural, ${ }^{9}$ still view deliberation as one of the best ways to resolve disputes, so the path chosen by the parties in resolving disputes is through peace. However, some people in Palu use mediation at the Religious Court Palu Class IA as a way to resolve disputes. They consider mediation to be an effective way to resolve inheritance disputes.

However, the Religious Court in Palu deals with a lot of inheritance cases; there are inheritance disputes that have been resolved, and some have not been resolved. This is the reason for the author to examine how to resolve inheritance disputes

\section{Literature Review}

\subsection{Settlement of inheritance dispute cases}

Inheritance is the heritage of the deceased which will be distributed to the heirs. ${ }^{10}$ In Islam, inheritance law is called faraid, which is the science that explains the procedure for the distribution of property from someone who has died

9 See Rusli Rusli, "Multikulturalisme Dalam Wacana Alquran," HUNAFA: Jurnal Studia Islamika 9, no. 1 (2012): 105-120.

${ }^{10}$ Dian Khairul Umam, Figh Mawaris, (Bandung: Pustaka Setia, 2006), 11.

e-ISSN: $2715-4580$ p-ISSN: 2715-8268 
with a predetermined distribution to be distributed to those who are entitled to receive it. 11

Islamic inheritance has legal sources or legal arguments from the Quran, Hadith, Ijma and ijtihad of the scholars. ${ }^{12}$ In the Quran, there are the verses, particularly sura al-Nisa 7 . However, this verse is still general. Legacy property is mentioned in this verse with the sentence ma taraka. Verses detailing the division of inheritance are found in verses 11-13. ${ }^{13}$

Among the hadiths that deals with the issue of inheritance is the hadith narrated by Ibn Abbas, in which the Prophet said, "give the part of the inheritance that has been determined the parts to those who are entitled, then what is left is allocated to the closest male relatives."14

Although the Quran and Hadith have given detailed provisions on the division of inheritance, but in some cases there is still a need for ijtihad, on matters that are not specified in the two sources of law. ${ }^{15}$ For example, regarding the inheritance for a sissy or khuntha, the inheritance that is not exhausted is divided to whom the rest is given, the

${ }^{11}$ Saifudin Arif, Praktek Pembagian Harta Peninggalan Berdasarkan Hukum Waris Islam, (Jakarta: PP Darunnajah, 2007), 5.

12 H.R. Otje Salman S., S.H, Hukum Waris Islam (Bandung: Aditama, 2006), 3.

13Sajuti Thalib, Hukum Kewarisan Islam di Indonesia (Jakarta, PT. Bina Aksara, 1981),7.

${ }^{14}$ Al-Bukhari, Sahih al-Bukhari, Vol. 4 (Kairo: Dar al-Sya'bi, nd), 181.

15 Rusli Rusli, "Fikih Ekologi Dan Karifan Tradisional: Tinjauan Terhadap Konsep Ihya' AlMawatdam Hima," Hunafa: Jurnal Studia Islamika (2008). mother's share if only together with the father or widower or widow. 16

In the Compilation of Islamic Law, ${ }^{17}$ Article 171 point $b$, it is stated that tirkah (inheritance) is "all the inheritance of the person who died before it was taken for the maintenance of the corpse, paying off debts and fulfilling the will" .18 While, Article 171 point $c$ reads: "An heir is a person who at the time of death is related by blood or marriage to the heir, Muslim, and not prevented by law from becoming an heir." From Articles 174, 181, 182 and 185, it can be seen that the heirs consist of (1) male heirs, such as father, son, brother, uncle, grandfather and husband; (2) female heirs, such as mother, daughter, sister, grandmother and wife; and (3) successor heirs, such as grandson or granddaughter of a son or daughter. ${ }^{19}$

So, according to the Compilation of Islamic Law, an heir is someone who is declared to have a kinship relationship either by blood (nasab), a relationship because of marriage or marriage and is Muslim and is not hindered from inheritance.

\section{Methodology}

${ }^{16}$ Otje Salman S, Hukum Waris Islam (Bandung, Aditama, 2006), 10.

17 For the study of the Compilation of Islamic Law, see Yunus, Haerunnisa, Rusli, Rusli, \& Abidin, Abidin. (2020). "The Concept of A Marriage Agreement in the Compilation of Islamic Law". International Journal of Contemporary Islamic Law And Society, 2(2), 35-45.

${ }^{18}$ Arsumi A. Rahman, et al, Ilmu Figh 3, $2^{\text {nd }}$ edition (Jakarta: IAIN Jakarta, 1986), 1.

${ }^{19}$ Muslih Maruzi, Pokok-Pokok Ilmu Waris (Semarang: PT. Pustaka Rizki Putra, 1997), 6.

e-ISSN: $2715-4580$ p-ISSN: $2715-8268$ 
This study uses qualitative approach $^{20}$, investigating settlement of inheritance disputes from Islamic law's perspective. The research site is the Religious Court of Palu, that deals with disputes of inheritance.

Data were collected through observation, indepth interview, and written material. Data analysis consists of several procedures: reduction and verification techniques with various data sources. $^{21}$ The reduced data is then analyzed reflecting on theoretical concepts used in this study. ${ }^{22}$

\section{Result and Discussion}

\subsection{Inheritance dispute resolution process}

The Religious Courts are one of the implementers of judicial power for

20 Nurdin, N., \& Yusuf, K. (2020). Knowledge management lifecycle in Islamic bank: the case of syariah banks in Indonesia. International Journal of Knowledge Management Studies, 11(1), 59-80.

https://doi.org/10.1504/ijkms.2020.105073;

Nurdin, Nurdin. (2019). Knowledge Integration Strategy in Islamic Banks. In Almeida Helena \& Sequeira Bernardete (Eds.), The Role of Knowledge Transfer in Open Innovation (pp. 118-138). Hershey, PA, USA: IGI Global; See also Rusli Rusli, "Pendekatan Fenomenologi Dalam Studi Agama Konsep, Kritik Dan Aplikasi," Islamica: Jurnal Studi Keislaman 2, no. 2 (2008): 141-153.

21 Muslih, Imam, Nurdin, Nurdin, \& Marzuki, Marzuki. (2020). Effectiveness of Marriage Services Through Information System Management (SIMKAH) at Palu City Religious Court International Journal of Contemporary Islamic Law And Society, 2(1), 20-35.

22 Iqbal, M., Rusli, R., \& Musyahidah, M. (2019). Management Strategies of Professional Zakat Funds for Mustahiq Family Welfare By Amil Zakat Body International Journal of Contemporary Islamic Law And Society, 1(1), 39-51.
Muslim people seeking justice regarding certain cases. ${ }^{23}$ One of the issues that have been resolved is the issue of inheritance disputes. In the Religious Courts, especially in the city of Palu, inheritance disputes are often resolved through mediation.

The process of resolving inheritance disputes is the same as the process of resolving other cases, in which, the procedure includes registration of cases, then the chairman of the court determines the panel of judges to deal with the inheritance dispute case. The process of summoning the two disputing parties is guided by the time determined by the panel of judges. In this case, the domicile of the disputing parties needs to be seen. This is also a reference point for judges to determine the day of settlement of inheritance disputes. The letter is sent to the appointed judge, then the appointed judge determines the day of the trial. After that, the panel of judges convenes in accordance with the applicable procedural law starting from the examination. ${ }^{24}$

However, in the inheritance dispute trial process, prior to the trial, the panel of judges began by mediating for both parties to the dispute, in accordance with Supreme Court Regulation No. 1 of 2016, which requires that all cases that go to court must be mediated beforehand. And if no meeting point is found

23 Sukarno Aburaera, 2012. Kekuasaan Kehakiman Indonesia (Makassar: Arus Timur, nd), 26.

${ }^{24}$ Interview with Syamsudin, A Judge of Religious Court, Class I A, Palu (23 August 2019). e-ISSN: $2715-4580$ p-ISSN: 2715-8268 
between the disputing parties, the case is then brought to trial. 25

With regard to mediation conducted in a closed room, it is in accordance with Article 5 paragraph (1) Supreme Court Regulation No. 1 of 2016, that "the mediation process is basically closed unless the parties wish otherwise." And mediation is carried out in the mediation room of the local court. This is in line with Article 11 paragraph (1) "Mediation is held in the Court Mediation room or at another place outside the Court as agreed by the parties."

In terms of motive, all of the litigants have good intentions. Likewise with attendance, it was almost found that there were no problems, because when a party deemed important could not attend, he was represented by his legal representative. This is justified by Article 5 paragraph (1), Supreme Court Regulation Number 1 Year: "In the event that the parties are unable to attend based on valid reasons as referred to in Article 6 paragraph (4), the legal counsel may represent the parties to mediate by showing a special power of attorney containing the authority of the attorney to make decisions." And if the two parties still disagree, then enter the trial stage. Then, in the management process, it takes quite a long time.

In the case of inheritance disputes in Palu, the management process takes a week, and in the case of disputes outside the city of Palu, it takes about a month. This is because the court, where a litigant files a lawsuit, coordinates back to the

${ }^{25}$ Ibid. court outside the area to process the incoming data, and then coordinates to the bailiff to summon both the defendants and plaintiff. ${ }^{26}$

Before making summons to the two disputing parties, a judge is required to examine the disputed cases that enter the court in order to identify the problem and provide legal considerations in deciding a case. In this case, the judge coordinated well with the components in the Palu religious court. All parties coordinate well with each other in the process of summoning both parties, for which they are required to bring evidence and show in front of the judge proof of the legality of ownership of an asset.

After the mediation stage, there are several next stages, namely the reading of the lawsuit, answers from the defendant, replik, duplicate, proof and site review. Judges in making decisions are through deliberation and consensus, after studying the entire series of trials. Before reading the verdict, the judge considers the results of the case analysis from judge 1, member 1 , with the judges of the assembly, then they are mixed into a decision. Thus, it can be said that the decision rests on three basic concepts of decision making, namely weighing, appealing, and deciding. ${ }^{27}$

After these stages, the judge makes a decision on the case. ${ }^{28}$ The judge's decision is a statement by the

\footnotetext{
26Interview with Syamsudin, A Judge of Religious Court, Class I A, Palu (23 August 2019).

27Ibid.

${ }^{28}$ Mertukosumo Suedikno, Hukum Acara Perdata Indonesia (Yogyakarta: Liberty, 1999), 175. e-ISSN: $2715-4580$ p-ISSN: 2715-8268
} 
judge as a state official who is authorized to be pronounced at the trial, and aims to end or resolve a case or dispute between various parties. Not only words, but also statements that are written and spoken by the judge before the trial. The judge is obliged to hear all parts of the lawsuit. make decisions on things that are not requested, or grant more than what is being sued.

In the process of resolving inheritance disputes at the Religious Court, Class 1 A, Palu, there are inhibiting factors. What made it difficult for the judge to go through the trial was that between the two disputing parties, one of them did not come. No one from the court hindered the dispute resolution process. Therefore, the judge postponed the trial, and this resulted in the trial taking quite a long time. ${ }^{29}$

\subsection{Islamic law review on inheritance dispute settlement}

At the time of the Prophet, the judicial process was very simple. If a problem happened to them, they immediately came to the Prophet to ask for a decision without having to wait for time or look for a certain place. In fact, most of the decisions made by the Prophet were more in the form of fatwas, compared to the court process that is understood today.

Although the process was simple, but the pillars of justice have been fulfilled, such as judges, law, the defendant (al-mahkum bih, al-mahkum

\footnotetext{
${ }^{29}$ Interview with Syamsudin, A Judge of Religious Court, Class I A, Palu (23 August 2019).
}

'alaih) and the plaintiff (al-mahkum lah). ${ }^{30}$ And, the cases were resolved in an informal way; however, the decisions made by the Prophet contain values of truth so that they are highly respected by all litigants.

The implementation of the settlement of inheritance dispute cases at the Palu Religious Court is certainly like what the Prophet did. Only the legal basis used is based on the text of the law, called the Compilation of Islamic Law, which is the basis for judges to determine the case and make decision. The value of justice is upheld to protect the rights of individuals in dispute in accordance with the vision and mission of the Religious Court, Class 1A, Palu, namely the Palu Religious Court class $1 \mathrm{~A}$ in line with the the trial of the Prophet.

In the process of resolving the inheritance dispute in the Religious Court, Class 1A, Palu, there must be a judge. A judge is a person appointed by the authorities to carry out an indictment and a dispute to decide, end, or settle a case. In Islam, there is an explanation of the primacy of those who take part in the judiciary, who know the truth and determine punishments based on that truth. The threat of hellfire for judges who know the truth, but do not make laws based on the truth.

Moreover, the parable of the judge who knows the truth but does not make laws based on the truth is like that of a fool who makes laws with his stupidity,

\footnotetext{
${ }^{30}$ Abdul Mannan, Etika Hakim dalam Penyelenggaraan Peradilan: Suatu Kajian dalam Sistem Peradilan Islam, $1^{\text {st }}$ edition (Jakarta: Prenada Media Group, 2007), 64.

e-ISSN: $2715-4580$ p-ISSN: $2715-8268$
} 
and his place is in hell. A fool, who does not meet the requirements of a judge, and makes the law correctly by chance, he is threatened by hell fire. The judge's decision that can be enforced is the decision of the judge of the first group, namely judges who know the truth and make laws based on that truth.

In this paper, there is one case that the author take. A case where Tinar Lapasse is the defendant with the husband's relatives (Zainudin bin Mena). This case went through three stages of trial, namely the Religious Court Class 1 $\mathrm{A}$ in Palu, then proceeded to the high court, and was decided in the Supreme Court. The search for justice is not easy, proper analysis is needed in a case so that the resulting decision can be accepted by each disputing party.

As with the decision in the case above that there was a cancellation of the claim after a review of the basic evidence of property ownership from Zainudin bin mena during the marriage, then the witnesses gave statements, so that the decision of the Supreme Court was born and changed what was the decision of the previous institution.

As the Prophet said that when there is a dispute between two parties who claim the truth, a decision may not be made after the judge has heard the statements of both parties. In this context, the Prophet required the evidence brought by the litigant, and an oath for the defendant. The proofs at the time of the Prophet include facts of truth (bayyinah), oaths (yamin), witnesses, and written evidence. ${ }^{31}$

${ }^{31}$ Ibid. 57

\section{Conclusions}

Based on the descriptions above, it can be concluded that the process of resolving inheritance disputes in the Palu Religious Court is the same as the settlement of cases that usually occur in courts. The process starts from registration, and then the chairman determines 3 judges to handle the inheritance case. Then, a summons is made from the disputing parties, and after that, each party shows evidence and witnesses to defend the ownership rights of the inherited property. Furthermore, the judge determines the share of the heirs based on the evidence of ownership and the kinship of the heirs.

However, the problem arises when the court summons both parties; but, one of the disputing parties does not arrive, so that the issue of inheritance disputes takes quite a long time.

\section{REFERENCES}

Al Quran dan Terjemahannya Revisi TerbaruSemarang: CV. As-Syifa, 1999.

Abdul Aziz Said, Nathan C. Funk and Ayse S. Kadayifci, "Islamic Approaches to Peace Conflict Resolution, dalam Abdul Aziz Said, Nathan C. and Ayse S. Kadayifci, Peace and Conflict Resolution in Islam, New York: University Press of America, 2007

Abdul Rahim. The Principles of Muhamma dan Jurisprudence, Jakarta: Sinar grafika

Abdul Wahhab Khlaf, Sejarah Hukum Islam, Ikhtisar, Bandung: Marja, 2005

e-ISSN: $2715-4580$ p-ISSN: 2715-8268 
International Journal of Contemporary Islamic Law and Society

Vol. 3 No. 1 Tahun 2021

Abdulkadir Muhammad, Hukum Waris Menurut KUHPerdata, Bandung: Citra Aditya Bhakti, 2000

Abdulkadir Muhammad, Hukum Waris MenurutKUHPerdata, Bandung: Citra Aditya Bhakti, 2000

Abu Daud, Sunanu Abi Daud, Vol. 2. Kairo: Mustafa Al-Babiy

Afdol, Penerapan Hukum waris Islam secara Adil, Airlangga Unyversity Press, Surabaya, 2003

Ahmad Saebani, Figh Mawaris, Bandung: Pustaka Setia, 2009

Al-Bukhori, Shahih Bukhori, Vol. 4. Cairo: Daar wa Mathba Asy-Sya'biy, T.t

Al-Sajastani, Abi Dawud Sulaiman Ibn al-Asy'as. Sunan Abi Dawud. Kairo: al-Misriyyah li al-Bananiyyah, 1988 Ukasah, Mahmud. Tarich al-Hukm fi al-Islam.Cet. I Kairo: Mu'assasah alMukhtar, 2002.

Amanat, Anisitus, Membagi Warisan Berdasarkan Pasal-Pasal Hukum Perdata BW, $1^{\text {st }}$ edition. Jakarta: PT. RajaGrafindo Persada 2000

Amin Husein Nasution, Hukum Kewarisan Islam Jakarta:

Rajagrafindo Persada 2012

Amir Syarifuddin, Pemikiran dalam Hukum Islam, Cet. 2 Padang, Penerbit Angkasa Raya: 1993

Arsumi A. Rahman, 1, Ilmu Figh 3, Jakarta IAIN Jakarta, 1986,

Badullah Ali Yusuf, The Meaning of the Holy Qur'an, Brentwood: Amana Corporation, 1991

Burhan Bungin, Peneiltan Kualitatif, Komunikasi, Ekonomi, Kebijakan Publik, dan Ilmu Sosial lainnya. 1st Edition, Jakarta: Kencana Prenada Media Group, 2007
Cik Hasan Bisri, Peradilan Agama di Indonesia, Jakarta: PT Raja Grafindo Persada, 2000

Dian Khairul Umam, Fiqh Mawaris, Bandung: Pustaka Setia, 2006

Donal Ari, et.al, Introduction to Research, diterjemahkan oleh Arief Rahman, Pengantar Penelitian dan Pendidikan, Surabaya: Usaha Nasional, nd

Elza Sary, penyelesaian sengketa harta waris dalam perkawinan poligami pada masyarakat tionghoa Muslim di Kota padang, Tesis S2 Program Studi Magister kenotariatan Universitas Andalas, 2014

Eman Suparman,Hukum Waris dalam perspektif Islam. Rafika Aditama. Bandung, 2005

Ernst Utrecht dan Moh. Saleh Djindang, Pengantar Dalam Hukum Indonesia, Jakarta: Ikhtiar, 1957

Ezmir, Metodologi Penelitian Kualitatif Analisis Data, 2nd edition. Jakarta: PT. Raja Grafindo Persada,2011

Farid Abdul Khiq, Fikih Islam, Jakarta: Amzah, 2005

Garry Goopaster, Negosiasi Dan Mediasi, ELIPS Project, Jakarta 1993

GunawanWidjajadan Ahmad Yani, HukumArbitrase, Jakarta: Rajawali Pers,2003

H. Abdurrahman, Kompilasi Hukum Islam di Indonesia, Jakarta: Akademika Pressindo, 2010

H. Riduan Syahrani, Materi Dasar Hukum Acara Perdata, Bandung: PT. Cipta Aditya Bakti, 2009

H.R. Otje Salman S., S.H, Hukum Waris Islam, Bandung, Aditama, 2006

H. Sulaiman Rasjid, Fiqih Islam, Bandung: PT. Sinar Baru Algensindo, 33 ${ }^{\text {rd }}$ edition, 2000

e-ISSN: $2715-4580$ p-ISSN: $2715-8268$ 
International Journal of Contemporary Islamic Law and Society

Vol. 3 No. 1 Tahun 2021

Habiburrahman, Hukum Kewarisan Islam di Indonesia ,Jakarta: Kencana 2011

Harahap, M Yahya, Hukum Acara Perdata, Jakarta: Sinar Grafika, 2004

Husein Umar, Metode Penelitian untuk Skripsi dan Tasir Bisnis, $4^{\text {th }}$ edition. Jakarta: PT. Raja Grafindo, 2000

I Made Sukanda, Mediasi Peradilan, Jakarta: Prestasi Pustaka Publisher, 2012

Imron Arifin, Penelitian Kualitatif Dalam Ilmu-ilmu Sosial dan Keagamaan, $3^{\text {rd }}$ edition. Malang: Kalimasada Press, 1996

Irawan Suhartono, Metode Penelitian Sosial, $5^{\text {th }}$ edition. Bandung: Remaja Rosdakarya, 2002

Irawan, penyelesaian sengketa waris adat pada masyarakat suku dayak ngaju di kecamatan kahayan hilir kabupaten pulang pisau provinsi kalimantan tengah, Tesis S2 Program Magister Kenotariatan Universitas Gajah Mada, 2009.

Iqbal, Muhammad, Rusli, Rusli, \& Musyahidah, Musyahidah. (2019). Management Strategies of Professional Zakat Funds for Mustahiq Family Welfare By Amil Zakat Body International Journal of Contemporary Islamic Law And Society, 1(1), 39-51.

Joni Emirzon, Alternatif Penyelesaian Sengketa di Luar Pengadilan Negosiasi, Mediasi, Konsiliasi, Arbitrase Jakarta: PT. Gramedai Pustaka Utama, 2001

Kartini Kartono, Pengantar Metode Riset Sosial, Cet. II; Bandung: Mandar Mas, 1990
Koto, Alaiddin. Sejarah Peradilan Islam. $1^{\text {st }}$ Edition. Jakarta: PT Rajagrafindo Persada, 2011

Lexy J. Moleong, Metodologi Penelitian Kualitatif, Cet. XVII; Bandung: PT. Remaja Rosdakarya, 2002

Madkur, Muhammad Salam. Peradilan dalam Islam. $4^{\text {th }}$ edition. Surabaya: PT Bina Ilmu, 1993

Mahkamah Agung, Naskah Akademis Tentang Pembentukan Hukum Melalui Yurisprudensi, Jakarta: Mahkamah Agung, 2005

Mannan, Abdul. Etika Hakim dalam Penyelenggaraan Peradilan: Suatu Kajian dalam Sistem Peradilan Islam. $1^{\text {st }}$ edition. Jakarta: Prenada Media Group, 2007

Mertukosumo Suedikno, Hukum Acara Perdata Indonesia. Yogyakarta Liberty, 1999

Metthew B. Milles dan A. Michael Hubarman, Analisis Data Kualitatif. Buku Tentang Metode-metode Baru, Trans. Tjecep Rohendi, $1^{\text {st }}$ edition. Jakrta: UI Press, 2005

Moh.Muhibbin, Abdul Wahid, Hukum Kewarisan Islam Sebagai Pembaruan Hukum Positif di Indonesia, Jakara: Sinar Grafika

Mohammed Abu Nimermediasi dalam hukum Islam, Jakarta: PT. RajaGrafindo Persada

MR. A. Pitlo, Hukum Waris: Menurut Undang-Undang Hukum Perdata Belanda, Jakarta: Intermasa, 1990

Muhammad Ali al-Shabuni, al Mawaris Fisy Syari'atil Islamiyyah 'Ala Dhani' al Kitab wa Sunnah.

Muhammad Ali Ash-Shabuni, HukumWaris Islam, Surabaya: AlIkhlas, 1995

e-ISSN: $2715-4580$ p-ISSN: 2715-8268 
Muhammad Daud Ali, Asas Hukum Islam, Jakarta, Rajawali Press, 1990

Muslih Maruzi, Pokok-Pokok Ilmu Waris (Semarang: PT. Pustaka Rizki Putra, 1997

Muslih, Imam, Nurdin, Nurdin, \& Marzuki, Marzuki. (2020). Effectiveness of Marriage Services Through Information System Management (SIMKAH) at Palu City Religious Court International Journal Of Contemporary Islamic Law And Society, 2(1), 20-35.

Mustofa Haffas, Hukum Waris Islam, Refika Aditama, Bandung, 2002

Nurdin, Nurdin. (2019). Knowledge Integration Strategy in Islamic Banks. In Almeida Helena \& Sequeira Bernardete (Eds.), The Role of Knowledge Transfer in Open Innovation (pp. 118-138). Hershey, PA, USA: IGI Global.

Nurdin, Nurdin, \& Yusuf, Khaeruddin. (2020). Knowledge management lifecycle in Islamic bank: the case of syariah banks in Indonesia. International Journal of Knowledge Management Studies, 11(1), 59-80. doi: 10.1504/ijkms.2020.105073

Ohn Echols dan Hasan Shadily, Kamus Inggris Indonesia, Jakarta: Gramedia Pustaka Utama, 2003

Abdul Manan, Penerapan Hukum Acara Perdata di Lingkungan Peradilan Agama, Jakarta: PT. Kencana, 2005.

Otje Salman. Hukum Waris Islam, Bandung, Aditama, 2006

Paulus Effendi Lotulung, Peranan Yurisprudensi Sebagai Sumber Hukum, Jakarta: Badan Pembinaan Hukum Nasional, 1997
Puslitbang Hukum dan Peradilan Badan Litbang Diklat Kumdil MA RI, Kedudukan dan Relevansi Yurisprudensi Untuk Mengurangi Disparitas Putusan Pengadilan, Jakarta: Penerbit Balitbang Pendidikan dan Pelatihan Hukum dan Peradilan MA RI, 2010

R. Soetojo Prawirohamidjojo, Hukum Waris Kodifikasi, Surabaya; Airlangga University Press, 2000

Rahman, M. Ibnu. Hukum Islam dalam Perspektif Filsafat. $1^{\text {st }}$ edition. Yogyakarta: Philosophy Press, 2001

Retnowulan Soetantio, Hukum Acara Perdata dalam Teori dan Praktek, Mandar Maju, Bandung, 1997

Robert K.Yin, Case Study Design and Methods, diterjemahkan oleh $\mathrm{M}$. Djauzi Mudzakir dengan judul: Studi Kasus Desain dan Metode, $1^{\text {st }}$ edition. Jakarta: PT.Raja Grafindo Persada, 2002

Roihan A Rasyid, Hukum Acara Peradilan Agama, Jakarta: PT Raja Grafindo, 2000

Roihan A. Rasyid, Hukum Acara Peradilan Agama Jakarta: Rajagrafindo Persada 2007

Rosady Ruslan, Metode Penelitian Public Relation dan Komunikasi, $4^{\text {th }}$ edition. Jakarta: PT. Raja Grafindo Persada, 2004.

Rusli Rusli, “An Analysis of Islamic Feminism in Indonesia: Reconstruction of Islamic Legal Issues on Gender Relations," Hunafa: Jurnal Studia Islamika 3, no. 1 (2006): 1-12, Accessed in https://www.jurnalhunafa.org/ind ex.php/hunafa/article/view/239.

e-ISSN: $2715-4580$ p-ISSN: 2715-8268 
Rusli Rusli, Islamic Feminism: Responses of Muslim Feminists to Gender Inequality in Indonesia (Palu: Irshed Press, 2006).

Rusli Rusli, “Fikih Ekologi Dan Karifan Tradisional: Tinjauan Terhadap Konsep Ihya' Al-Mawatdam Hima," Hunafa: Jurnal Studia Islamika (2008).

Rusli Rusli, "Gagasan Khaled Abu Fadl Tentang "Islam Moderat Versus Islam Puritan (Perspektif Sosiologi Pengetahuan)," Jurnal Ilmiah Ilmu Ushuluddin 8, no. 1 (2009): 99-123.

Rusli Rusli, "Multikulturalisme Dalam Wacana Alquran," HUNAFA: Jurnal Studia Islamika 9, no. 1 (2012): 105120.

Rusli Rusli, "The Role of Family in Preventing Social Conflict in Society From Islamic Perspectives," HUNAFA: Jurnal Studia Islamika 17, no. 1 (2020): 108-122.

Iqbal, Muhammad, Rusli, Rusli, \& Musyahidah, Musyahidah. (2019). Management Strategies of Professional Zakat Funds for Mustahiq Family Welfare By Amil Zakat Body INTERNATIONAL JOURNAL OF CONTEMPORARY ISLAMIC LAW AND SOCIETY, 1(1), 39-51.

S. Margono, Metode Penelitian Pendidikan, Cet. II; Jakarta: Rineka Cipta, 2000

S. Nasution, Metode Research Penelitian Ilmia, $4^{\text {th }}$ edition. Jakarta: PT.Bumi Aksara, 2001

Sabarudin, pelaksanaan putusan sengketa waris yang diselesaikan melalui mediasi di mahkamah syar'iyah lhoksukon studi kasus atas putusan nomor 493/pdt.g/2015/ms-lsk, Tesis S2
Program Studi Magister Hukum Islam Universitas Sumatra Uatara, 2016

Saifudin Arif, Praktek Pembagian Harta Peninggalan Berdasarkan Hukum Waris Islam, Jakarta: PP Darunnajah, 2007

Sajuti Thalib, Hukum Kewarisan Islam di Indonesia, Jakarta, PT. Bina Aksara, 1981.

Sayadi, Wajidi. Sejarah Pembentukan dan Perkembangan Hukum Islam. $2^{\text {nd }}$ edition. Jakarta: PT Rajagrafindo Persada, 2002

Sebastiaan Pompe, Runtuhnya Institusi Mahkamah Agung, Jakarta: Lembaga Kajian dan Advokasi Untuk Independensi Peradilan, 2012

Simon Shetreet, Judicial Independence, Netherlands: Martinus Mijhoff Publisher, 1985

Soedjono Dirdjosisworo, Filsafat Peradilan Pidana dan Perbandingan Hukum, Bandung: CV. Armico, 1984

Soetojo Prawirohamidjojo, Hukum Waris Kodifikasi, Surabaya Airlangga University Press 2015.

Sudikno Mertokusumo, Hukum Acara

Perdata Indonesia, $6^{\text {th }}$ edition.

Yogyakarta: Liberty, 2002

Sudikno Mertokusumo, Mengenal Hukum

Suatu Pengantar, Yogyakarta:

Liberty Yogyakarta, 2003.

Sukaenah, Sukaenah, Rusli, Rusli, \& B, M. Taufan. (2020). The Effectiveness of Indonesia Supreme Court Regulation Number 1 Year 2016 Concerning Mediation of Marriage Disputes International Journal of Contemporary Islamic Law And Society, 2(1), 63-80. 
Sukarno Aburaera, Kekuasaan Kehakiman Indonesia. Arus Timur, Makassar 2002

Suparman Usman dan Yusuf Somawinata, Figh Mawaris,Hukum kewarisan Islam Jakarta: Tintamas, 1982

Sutrisno Hadi, Metodologi Research Jilid I, $2^{\text {th }}$ edition. Yogyakarta: Andi 1997

Suyud Margono ADR alternative dispute resolution $\mathcal{E}$ Arbitrase, $2^{\text {nd }}$ edition. Bogor :Ghalia Indonasia, 2004

Taufik Rahman, Hadis-hadis hukum, Cet 1 , Bandung: PUSTAKA SETIA, 2000

A.M. Basalamah "Pembagian Waris Menurut Islam", Jakarta: Gema Insane Press, 1995

UU peradilan, Undang - Undang RI No.7 Tahun 1989, Semarang : Aneka Ilmu,1990.

Winarno Surakhmad, Dasar dan Teknik Research. Pengentar Metodologi Ilmiah, Bandung: Torsito, 1978.

Yulfia, penyelesaian sengketa waris dalam perkawinan poligami di pengadilan Agama kelas i A padang, Tesis S2 Program Studi Magister Hukum Islam Universitaz Andalas.

Yunus, Haerunnisa, Rusli, Rusli, \& Abidin, Abidin. (2020). The Concept of A Marriage Agreement in the Compilation of Islamic Law International Journal Of Contemporary Islamic Law And Society, 2(2), 35-45. 